\title{
Gestational Cadmium Exposure-Induced Ovotoxicity Delays Puberty through Oxidative Stress and Impaired Steroid Hormone Levels
}

\author{
Jawahar B. Samuel • Jone A. Stanley • \\ Rajendran A. Princess • Paulraj Shanthi • \\ Maria S. Sebastian \\ Published online: 4 March 2011 \\ (C) American College of Medical Toxicology 2011
}

\begin{abstract}
Cadmium (Cd), an environmental pollutant, has been shown to be highly toxic to both humans and animals. Its widespread industrial use has led to its accumulation in the environment. $\mathrm{Cd}$ has been shown to target multiple organs following acute intoxication, causing nephrotoxicity, immunotoxicity, osteotoxicity, and reproductive toxicity. $\mathrm{Cd}$ can cross the placental barrier and cause a wide range of defects during fetal development. The current study was aimed to assess the effect of $\mathrm{Cd}$ on the female reproductive system. Female rats were exposed to Cd [50/200 ppm] from embryonic day 9 to 21 through drinking water. Serum steroid hormone concentrations, hematological parameters, antioxidant enzyme levels, and ovarian histopathology were described. Water consumption, gravid uterine/body weight decreased in both the doses of Cd-treated dams. The hematological parameters analyzed in rat pups showed a significant reduction in both doses of $\mathrm{Cd}$ studied, while
\end{abstract}

J. B. Samuel $(\bowtie) \cdot$ R. A. Princess $\cdot$ P. Shanthi

Department of Zoology, St. John's College,

Thirunelveli, TN 627002, India

e-mail: drbjsamuel@yahoo.co.in

\section{J. A. Stanley}

Department of Endocrinology, Dr ALM Post Graduate Institute of

Basic Medical Sciences, University of Madras,

Taramani Campus,

Chennai, TN 600113, India

\section{S. Sebastian}

Department of Zoology, St. Xavier's College,

Thirunelveli, TN 627002, India

Present Address:

J. A. Stanley

Department of Veterinary Integrative Biosciences,

College of Veterinary Medicine \& Biomedical Sciences,

Texas A\&M University,

College Station, TX 77843, USA hemoglobin showed a significant reduction in $200 \mathrm{ppm} \mathrm{Cd}$ treatment alone. $\mathrm{MCHC}$ levels did not show any variation in $50 \mathrm{ppm} \mathrm{Cd}$ treatment, while $200 \mathrm{ppm} \mathrm{Cd}$ treatment significantly increased. Specific activities of superoxide dismutase, catalase, glutathione peroxidase, glutathione reductase, glutathione- $S$-transferase, and serum testosterone, estradiol, and progesterone were significantly decreased. The levels of hydrogen peroxide and lipid peroxidation were increased in 50 and $200 \mathrm{ppm} \mathrm{Cd}$-treated rats. These changes were accompanied with disrupted ovarian histoarchitecture, an extended estrous cycle, and delayed pubertal onset in Cd-treated rats. The data generated from the present study suggest that gestational $\mathrm{Cd}$ treatment induces ovarian toxicity and reproductive dysfunction through increased oxidative stress.

Keywords Cadmium · Ovary · Oxidative stress · Puberty · Anemia

\section{Introduction}

Cadmium $(\mathrm{Cd}$; atomic number 48 ; relative atomic mass 112.40) has been recognized as an occupational health hazard for many decades. Cd exists widely in the environment, as it is a constituent of sulfide ores of zinc $(\mathrm{Zn})$, lead $(\mathrm{Pb})$, and copper $(\mathrm{Cu})$ [1]. In addition, the industrial emission particularly from metal refining industries [2] has resulted in increased accumulation of $\mathrm{Cd}$ in the environment. $\mathrm{Cd}$ commonly exists in +2 state and has a long biological half-life of 15-30 years [3], mainly due to its low rate of excretion from the body, and accumulates in blood, kidney, and liver as well as in the reproductive organs [4-6]. Hence, it has elicited diverse toxic effects and caused nephrotoxicity, carcinogenity, teratogenicity, endo- 
crine, and immune toxicities [6-8]. India has contributed substantially (700 tons) to the worldwide production of $\mathrm{Cd}$ (18,800 tons) during 2008-2009 [9]. In Mumbai, India, lung injury and respiratory distress syndrome were identified among workers in the silver jewellery industry accidentally exposed to metal $(\mathrm{Cd})$ fumes $[10,11]$. Cd has also been shown to effect reproductive toxicity either directly targeting gonads or indirectly by interfering with the hypothalamus-pituitary-gonadal axis [12]. Pregnant and lactating female animals were reported to absorb and retain substantially more dietary $\mathrm{Cd}$ than do their non-pregnant counterparts [13] and $\mathrm{Cd}$ can be transferred to fetus [14, 15]. Acute $\mathrm{Cd}$ exposure-induced toxicity in pregnant rats were known to cause placental necrosis and hemorrhages, with an increased rate of fetal death [16]. It also decreases production of hCG and inhibits placental transfer of oxygen and nutrients to the fetus [17]. Preterm delivery and lower birth weight of newborn infants were reported in women occupationally exposed to $\mathrm{Cd}$ and also the birth weight is inversely correlated with maternal and cord blood $\mathrm{Cd}$ concentrations [18]. Laudanski et al. [19] reported that the mean blood concentration of $\mathrm{Cd}$ in mothers of preterm infants was higher than that of women who went to full term in an area with high amounts of lead and cadmium in the soil. All the above studies clearly suggest that occupational $\mathrm{Cd}$ treatment had adverse effects on female reproductive system and pregnancy outcome. The goal of the present investigation was to understand the mechanisms underlying the gestational $\mathrm{Cd}$ treatment-induced ovotoxicity and the delay in sexual maturation. The specific objectives were (1) to study the effect of gestational exposure to $\mathrm{Cd}$ on the reproductive effects in mother rats, (2) to study the effect of gestational exposure to $\mathrm{Cd}$ on the changes in hematological and steroid hormonal profiles in developing rats, and (3) to study the effect of gestational exposure to $\mathrm{Cd}$ on the histological alterations in ovarian tissue, pubertal onset, and length of estrous cycles in developing rats.

\section{Materials and Methods}

Animals

Proven fertile female Wistar rats (Rattus norvegicus) from our own colony maintained in our animal house were used in the present study. They were maintained in plastic animal cages in a light-controlled room ( $12 \mathrm{~h}$ day light $)$ at $23-25^{\circ} \mathrm{C}$ and provided with standard rat pellet diet and clean drinking water ad libitum. Male rats (200-250 g body weight) were allowed to mate with proven-fertile female rats (1:2) at late proestrous phase. Successful mating was confirmed by the presence of vaginal plug or sperm in the morning vaginal smear, and the day was counted as "0" day post-coitum and the following day as embryonic day (ED) 1. The day of parturition was counted as postnatal day (PND) 1. Pregnant rats $(n=54)$ were divided into three groups: (I) Control $(n=18)$, (II) $50 \mathrm{ppm} \mathrm{Cd}$ containing water from ED9-ED21 $(n=18)$, (III) 200 ppm Cd containing water from ED9-ED21 $(n=18)$.

On the day of birth, male pups were removed and female pups were left with their respective mother (four female pups per mother). After weaning, on PND 10 and 21, female pups from six mother rats $(n=24 ; 4$ pups/mother $)$ from each group [control, $\mathrm{CdCl}_{2}, 50 \mathrm{ppm}(50 \mathrm{mg} / \mathrm{L})$, $\left.\mathrm{CdCl}_{2}, 200 \mathrm{ppm}(200 \mathrm{mg} / \mathrm{L})\right]$ were killed by decapitation. Blood and ovarian tissue were then collected. Female pups from three mother rats $(n=12 ; 4$ pups/mother) from each group [control, $\mathrm{CdCl}_{2}, 50 \mathrm{ppm}(50 \mathrm{mg} / \mathrm{L}), \mathrm{CdCl}_{2}, 200 \mathrm{ppm}$ $(200 \mathrm{mg} / \mathrm{L})]$ were used to study the pubertal onset and estrous cyclicity. All the chemicals used in the present study were purchased from sigma chemical company, St. Louis, USA.

\section{Reproductive Effects}

The maternal reproductive toxic effects of $\mathrm{Cd}$ were calculated by measuring the number of fetus per dam, number of implantation sites, number of resorption sites, gravid uterine weight, and dam weight. Under general anesthesia, an incision was made in the abdomen of pregnant female rats $(n=3)$ from each group [control, $\mathrm{CdCl}_{2}, 50 \mathrm{ppm}(50 \mathrm{mg} / \mathrm{L}), \mathrm{CdCl}_{2}$, $200 \mathrm{ppm}(200 \mathrm{mg} / \mathrm{L})]$ on ED 19, and the gravid uterus was removed and weighed accurately.

\section{Hematological Analysis}

A Neubauer chamber was used to determine erythrocyte numbers, and hematocrit levels were measured by microhematocrit method and the hemoglobin levels were measured by cyanmethemoglobin method.

Pubertal Onset and Estrous Cycle

Vaginal opening was observed in rats from PND 22, every $24 \mathrm{~h}$ to determine puberty, as this was used as an index of onset of puberty. After the onset of puberty, vaginal smears were examined every morning as described in our previous paper [20].

Tissue Preparation for Enzyme Assays

Ovary was dissected out and washed in ice-cold physiological saline repetitively, weighed accurately, and placed in $0.1 \mathrm{~mol} / 1$ Tris-HCl buffer, $\mathrm{pH}$ 7.4. The samples were homogenized well to produce $10 \%$ homogenates. The protein 
concentrations of the tissue homogenates were determined by the method of Lowry et al. [21] using bovine serum albumin as the standard. The detailed methodology for the antioxidant enzymes and reactive oxygen species assays were described in our earlier paper [20].

\section{Antioxidant Enzymes}

Superoxide dismutase (SOD) activity was estimated according to the method of Marklund and Marklund [22]. The enzyme activity was expressed as units per milligram protein. Catalase activity was quantified colorimetrically [23]. The catalase activity was expressed as millimoles of hydrogen peroxide $\left(\mathrm{H}_{2} \mathrm{O}_{2}\right)$ utilized per minute per milligram protein. Glutathione peroxidase (GPx) activity was determined colorimetrically [24]. GPx enzyme activity was expressed as units per milligram protein. Glutathione- $S$ transferase (GST) activity was determined by estimating the amount of enzyme that catalyzed the conjugation of a known amount of 1-chloro-2, 4-dibenzene with GSH [25]. GST enzyme activity was expressed as micromoles of GSH consumed per minute per milligram protein. Glutathione reductase (GR) activity was assayed colorimetrically [26]. GR activity was expressed as nanomoles of NADPH oxidized per minute per milligram protein.

\section{Reactive Oxygen Species}

Lipid peroxidation (LPO) was measured by the method Devasagayam and Tarachand [27]. The results were expressed as nanomoles of MDA formed per milligram protein. $\mathrm{H}_{2} \mathrm{O}_{2}$ production was assessed spectrophotometrically, and the content was expressed as micromoles per minute per milligram protein.

\section{Radioimmunoassay}

Serum levels of estradiol, progesterone, and testosterone were estimated by radioimmunoassay as we described earlier [28]. The maximum binding of the estradiol antibody was $37-40 \%$, and the sensitivity of the assay was $0.3 \mathrm{pg} / \mathrm{ml}$. The concentration of estradiol in serum is expressed as picograms per milliliter. The percentage of binding of the testosterone antibody was $36 \%$, and the sensitivity of the assay was $0.3 \mathrm{pg}$ testosterone per milliliter. Testosterone levels in serum is expressed as nanograms per milliliter. The maximum binding of progesterone antibody was $40 \%$, and sensitivity of the assay was $0.3 \mathrm{pg} / \mathrm{ml}$. Progesterone level is expressed as nanograms per milliliter.

\section{Ovarian Histopathology}

The ovaries were removed from the animals and immersed in Bouin's fixative for 2-4 h. Tissues were dehydrated, embedded in paraffin, sectioned $(5 \mu \mathrm{m})$, and stained with hematoxylin and eosin and analyzed under Nikon research microscope.

\section{Statistical Analysis}

Data were statistically analyzed using analysis of variance. When the $F$ ratio was statistically significant, the data were subjected to Student's Newman-Keul's test. Values were considered significant at $p<0.05$.

\section{Results}

Cd treatment leads to dose-dependent changes in the specific activities of ovarian antioxidant enzymes, free radicals, and hormones.

\section{Reproductive Effects}

Characteristics of rats subjected to different $\mathrm{Cd}$ doses during pregnancy are described in Table 1 . As shown, the 50 and $200 \mathrm{ppm} \mathrm{Cd}$ had significantly reduced water

Table 1 Effect of Cd treatment on reproductive effects on ED19 rats

\begin{tabular}{|c|c|c|c|c|c|c|c|c|}
\hline & $\begin{array}{l}\text { Initial body } \\
\text { weight }(\mathrm{g})\end{array}$ & $\begin{array}{l}\text { Final body } \\
\text { weight (g) }\end{array}$ & $\begin{array}{l}\text { Food } \\
\text { consumption } \\
\text { (g) }\end{array}$ & $\begin{array}{l}\text { Water } \\
\text { consumption } \\
(\mathrm{ml})\end{array}$ & $\begin{array}{l}\text { Gravid } \\
\text { uterine } \\
\text { weight (g) }\end{array}$ & $\begin{array}{l}\text { Number } \\
\text { of fetuses }\end{array}$ & $\begin{array}{l}\text { Number } \\
\text { of implantation } \\
\text { sites }\end{array}$ & $\begin{array}{l}\text { Number } \\
\text { of resorption } \\
\text { sites }\end{array}$ \\
\hline Control & $188 \pm 5.7$ & $283 \pm 5.9$ & $16.80 \pm 0.8$ & $31.12 \pm 2.81$ & $57.8 \pm 2.1$ & $12.41 \pm 0.81$ & $13.3 \pm 0.74$ & 0 \\
\hline 50 ppm Cd & $186 \pm 6.3$ & $269 \pm 6.3^{\mathrm{a}}$ & $15.71 \pm 0.9$ & $25.47 \pm 2.54^{\mathrm{a}}$ & $43.2 \pm 0.91^{\mathrm{a}}$ & $11.38 \pm 0.34$ & $12.5 \pm 0.85$ & $0.41 \pm 0.03^{\mathrm{a}}$ \\
\hline 200 ppm Cd & $183 \pm 6.8$ & $251 \pm 7.3^{\mathrm{a}}$ & $14.83 \pm 0.61^{\mathrm{a}}$ & $19.45 \pm 1.31^{\mathrm{a} . \mathrm{b}}$ & $37.9 \pm 0.84^{\mathrm{a}}$ & $8.55 \pm 0.51^{\mathrm{a}, \mathrm{b}}$ & $7.9 \pm 0.43^{\mathrm{a}, \mathrm{b}}$ & $1.1 \pm 0.07^{\mathrm{a}, \mathrm{b}}$ \\
\hline
\end{tabular}

Each value represents the mean and SEM of three pregnant female rats. See "Materials and Methods" for experimental details. Statistical significance of difference among groups at $p<0.05$

${ }^{\mathrm{a}}$ Control versus experiment

${ }^{\mathrm{b}} 50$ versus $200 \mathrm{ppm}$ 
consumption and the final body weight of dams. The gravid uterine weight also recorded significant decrease in rats exposed to both doses of $\mathrm{Cd}$. In order to test the reproductive toxic effects of $\mathrm{Cd}$, we first recorded the number of fetus per dam, implantation sites, and resorption sites in ED19 rats exposed to $\mathrm{Cd}$. The number of fetus and the number of implantation sites showed a significant reduction in $200 \mathrm{ppm}$ Cd-treated group, while the resorption sites significantly increased in ED19 rats exposed to Cd.

\section{Body and Ovary Weight}

Gestational exposure to $\mathrm{Cd}$ significantly reduced the ovary weight in $200 \mathrm{ppm}$ Cd-treated group, while both the doses [50 and $200 \mathrm{ppm}$ ] significantly reduced the body weight on PND10 and PND21 rats (Table 2).

\section{Hematological Analysis}

The hematocrit (PND10) and M.C.V levels (PND10 and $21)$ in rat pups showed a significant reduction in both doses $(50 / 200 \mathrm{ppm})$ of $\mathrm{Cd}$ studied, while hemoglobin content showed a significant reduction in $200 \mathrm{ppm} \mathrm{Cd}$ treatment alone. MCHC level significantly increased in $200 \mathrm{ppm}$ Cdtreated rats. However, number of erythrocytes increased significantly on PND10 and 21 by 200 ppm Cd treatment and on PND10 by 50 ppm Cd treatment (Table 3).

\section{Histopathology}

In order to check, whether the decreased body/ovary weight and the impaired hematological parameters were associated with the histoarchitecture of ovary, we studied the histopathology of ovary of experimental offspring.

Figure 1a-c represents the ovarian histoarchitecture of control, $50 \mathrm{ppm}, 200 \mathrm{ppm}$ Cd-treated rats at PND10. The $50 \mathrm{ppm} \mathrm{Cd}$ treatment affected both primary and secondary

Table 2 Effect of gestational exposure to $\mathrm{Cd}$ on body and ovary weight in developing rats (PND 10 and 21)

\begin{tabular}{|c|c|c|c|c|}
\hline & \multicolumn{2}{|c|}{ Body weight (g) } & \multicolumn{2}{|c|}{ Ovary weight (mg) } \\
\hline & PND10 & PND21 & PND10 & PND21 \\
\hline Control & $9.13 \pm 0.48$ & $22.3 \pm 1.41$ & $20.2 \pm 2.5$ & $33.1 \pm 2.12$ \\
\hline $50 \mathrm{ppm} \mathrm{Cd}$ & $7.1 \pm 0.61^{\mathrm{a}}$ & $19.2 \pm 1.38^{\mathrm{a}}$ & $16.2 \pm 1.8$ & $29.7 \pm 1.31$ \\
\hline 200 ppm Cd & $5.9 \pm 0.31^{\mathrm{a}, \mathrm{b}}$ & $17.1 \pm 1.33^{\mathrm{a}}$ & $13.6 \pm 1.1^{\mathrm{a}}$ & $26.4 \pm 1.40^{\mathrm{a}}$ \\
\hline
\end{tabular}

Each value represents the mean and SEM of 24 female rats (from six mothers). See "Materials and Methods" for experimental details. Statistical significance of difference among groups at $p<0.05$

${ }^{\mathrm{a}}$ Control versus experiment

b 50 versus 200 ppm

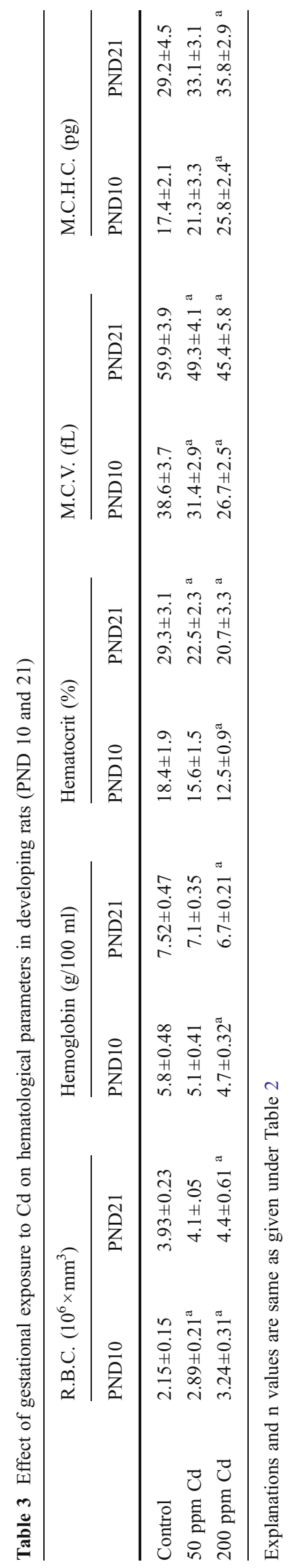



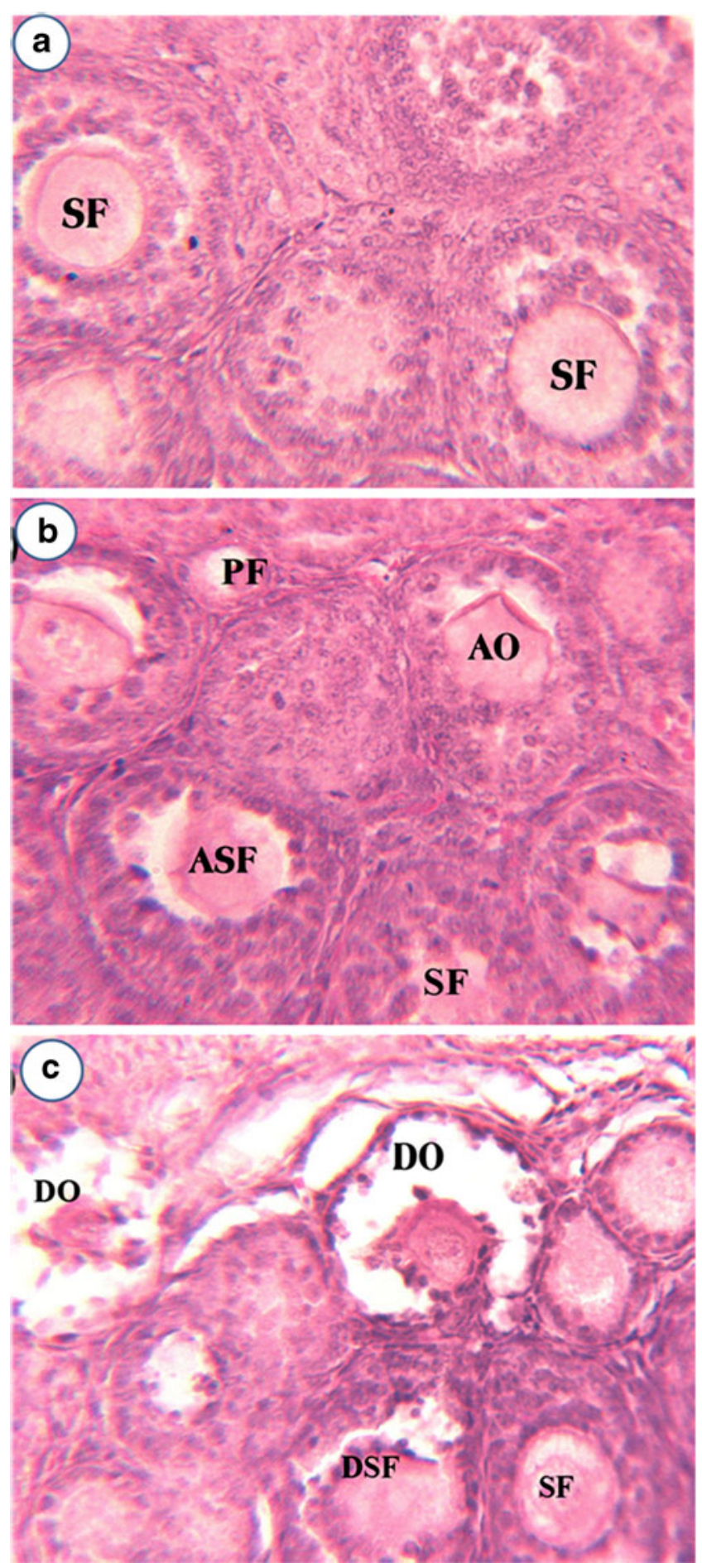

Fig. 1 Effect of gestational exposure to $\mathrm{Cd}$ on histoarchitecture of control (a), $50 \mathrm{ppm} \mathrm{Cd} \mathrm{(b),} \mathrm{and} 200 \mathrm{ppm} \mathrm{Cd} \mathrm{(c)} \mathrm{ovary} \mathrm{in} \mathrm{developing}$ rats (PND10). $P F$ primary follicle, $A S F$ atretic secondary follicle, $A O$ altered oocytes, $D S F$ disorganized secondary follicle, Co cumulus oophorus, $D O$ deformed oocytes, $O o$ oocytes, $S F$ secondary follicle

follicles in PND10 ovary, while the secondary follicles experienced heavy damage due to cell dissociation, oocyte resorption, and also loss of cells in follicular epithelium with a deformed oocyte in the center was observed. Theca interna and theca externa also appeared to be affected (Fig. 1b). The $200 \mathrm{ppm} \mathrm{Cd}$ treatment leads to disorganized secondary follicles and secondary follicles with altered oocytes due to onset of resorption on PND 10 ovary (Fig. 1c). Figure $2 \mathrm{a}-\mathrm{c}$ represents the ovarian histoarchitecture of control, $50 \mathrm{ppm}, 200 \mathrm{ppm}$ Cd-treated rat ovary on PND21. Cd treatment has lead to complete loss of cumulus
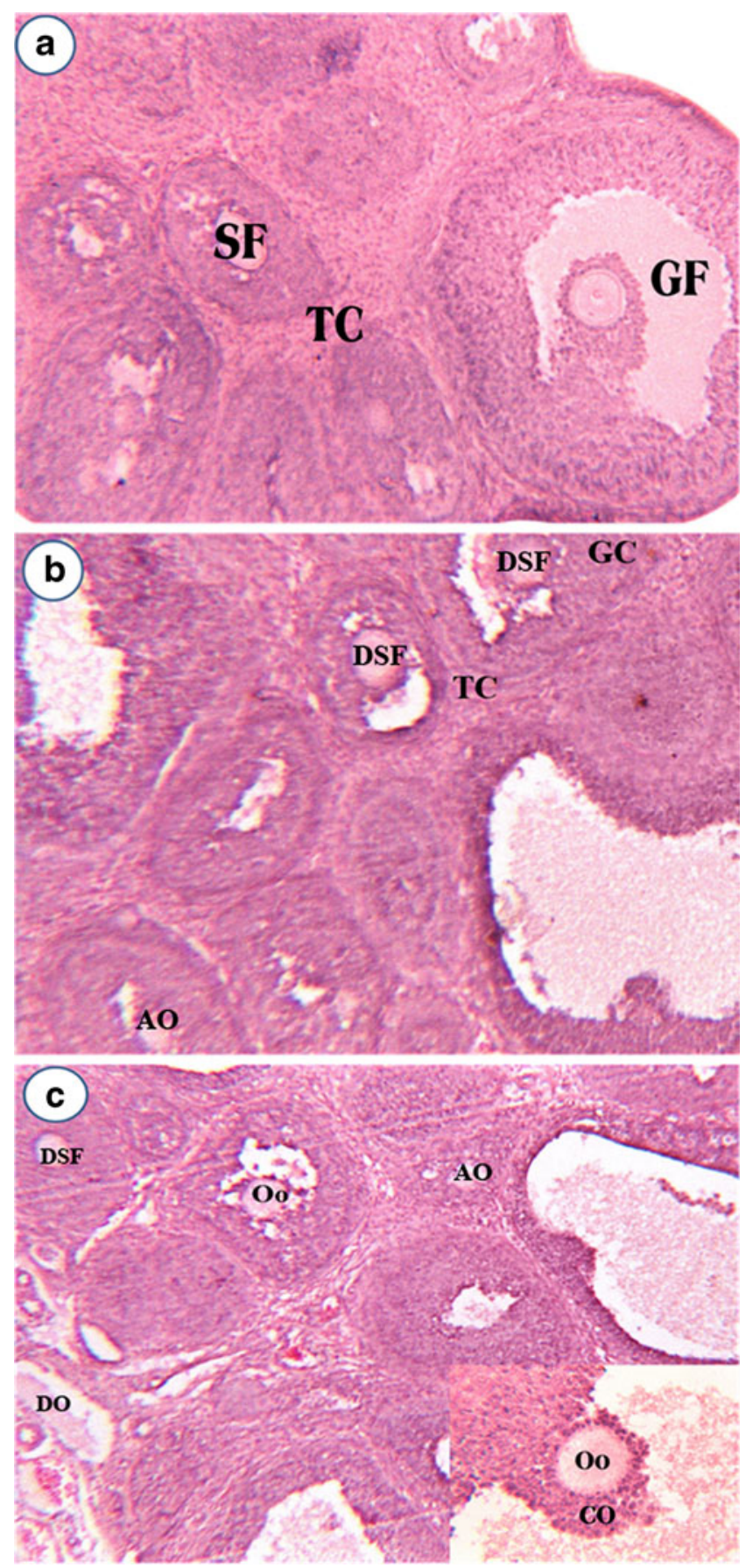

Fig. 2 Effect of gestational exposure to $\mathrm{Cd}$ on histoarchitecture of control (a), 50 ppm Cd (b), and 200 ppm Cd (c) ovary in developing rats (PND21). Explanations and $n$ values are same as given under Fig. 1 
oophorus and the remnants of disorganized granulosa cells in the antral fluid. Shrunken oocyte was evidenced with no trace of a nucleolus. Cd treatment (50 ppm) resulted in more numbers of follicles at various stages of degeneration, and the graffian follicles are found scattered throughout the ovary without oocytes (Fig. 2b). Cd treatment (200 ppm) on PND21 ovary revealed numerous atretic follicles at various stages of degeneration. In atretic follicles, the cumulus oophorus was completely lost and the remnants of disorganized granulosa cells were seen suspended in the antral fluid. The cumulus oophorus has lost a group of granular cells on one side, facing the antral cavity. The oocyte lacks zona pellucida and nucleolus. The cumulus oophorus has lost the oocyte in one of the Graafian follicles (Fig. 2c).

\section{Onset of Puberty}

Vaginal opening has been used as an index of onset of puberty. To evaluate the effect of $\mathrm{Cd}$ on the onset of puberty, we observed the vaginal opening every $24 \mathrm{~h}$ in rats from PND22 onwards (Fig. 3). Puberty was significantly delayed in Cd-treated rats in a dose-dependent manner.

\section{Estrous Cyclicity}

In order to evaluate the effect of $\mathrm{Cd}$ on the duration of estrous cycle, vaginal cytology was determined daily (Fig. 4). The estrous cycle was significantly extended in metestrus and diestrus stage in both doses of Cd tested.

\section{Antioxidant Enzymes}

Figure 5 represents the effect of $\mathrm{Cd}$ on the specific activities of antioxidant enzymes in rat ovary. The specific activity of

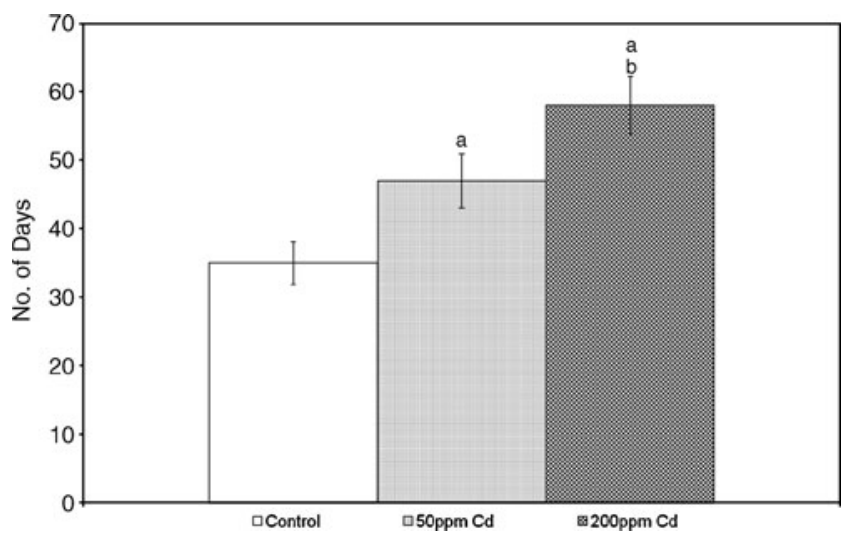

Fig. 3 Effect of gestational exposure to $\mathrm{Cd}$ on pubertal onset in developing rats. Each bar represents the mean and the vertical line above denotes the SEM of 12 female rats (from three mothers). See "Materials and Methods" for experimental details. Statistical significance of difference among groups at $p<0.05$. Control versus experiment (a); 50 versus $200 \mathrm{ppm}(b)$

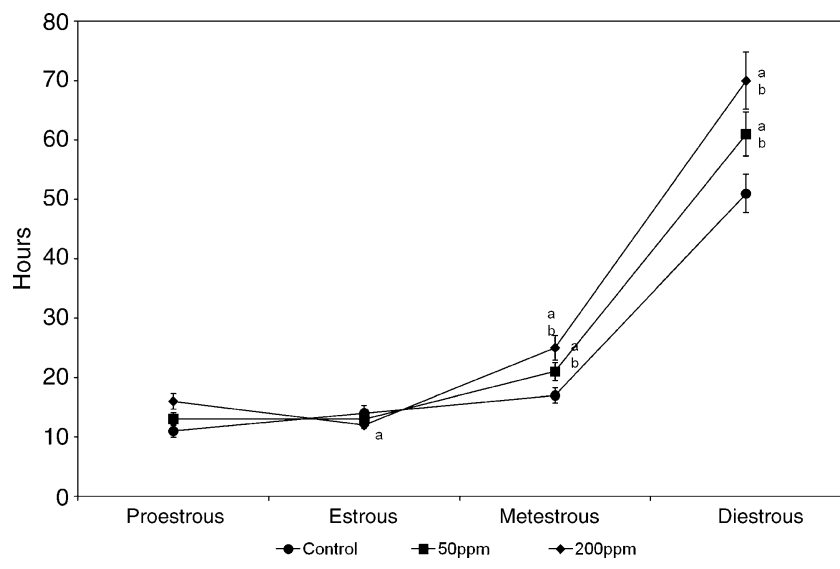

Fig. 4 Effect of gestational exposure to $\mathrm{Cd}$ on estrous cyclicity in developing rats. Explanations and $n$ values are same as given under Fig. 3

SOD, catalase (CAT), GPx, GR, and GST showed a dosedependent significant decrease in ovary of both treatment groups when compared with control.

\section{Lipid Peroxidation and $\mathrm{H}_{2} \mathrm{O}_{2}$ Concentration}

Figure 6 represents the concentrations of LPO and $\mathrm{H}_{2} \mathrm{O}_{2}$ generation in control, 50 and $200 \mathrm{ppm} \mathrm{Cd}$-treated rat ovary. Increased concentrations of LPO and $\mathrm{H}_{2} \mathrm{O}_{2}$ generation were observed in Cd-treated rats.

\section{Serum Steroid Hormones}

Table 4 represents circulating levels of steroid hormones in control, $50 \mathrm{ppm}$, and $200 \mathrm{ppm}$ Cd-treated rats. Both doses of $\mathrm{Cd}$ decreased steroid hormones at PND 10 and 21 when compared with control.

\section{Discussion}

The major physiological function of the female reproductive system is to produce ovum necessary for healthy progeny. Ovarian steroid hormones play a vital role in the production of ovum and other functions associated with reproductive behavior. The hormones secreted by the hypothalamus and pituitary also regulate regular cyclical changes in the ovary and endometrium. $\mathrm{Cd}$ has been shown to target ovary and suppress the synthesis and secretion of hormones [29].

Recently, we have reported the hexavalent chromium (CrVI)-induced delay in follicular development, impaired ovarian steroidogenesis [28, 30], delayed puberty, and associated oxidative stress [20]. In the present study, body weight and ovarian weight were decreased significantly which may be due to the decreased availability and 

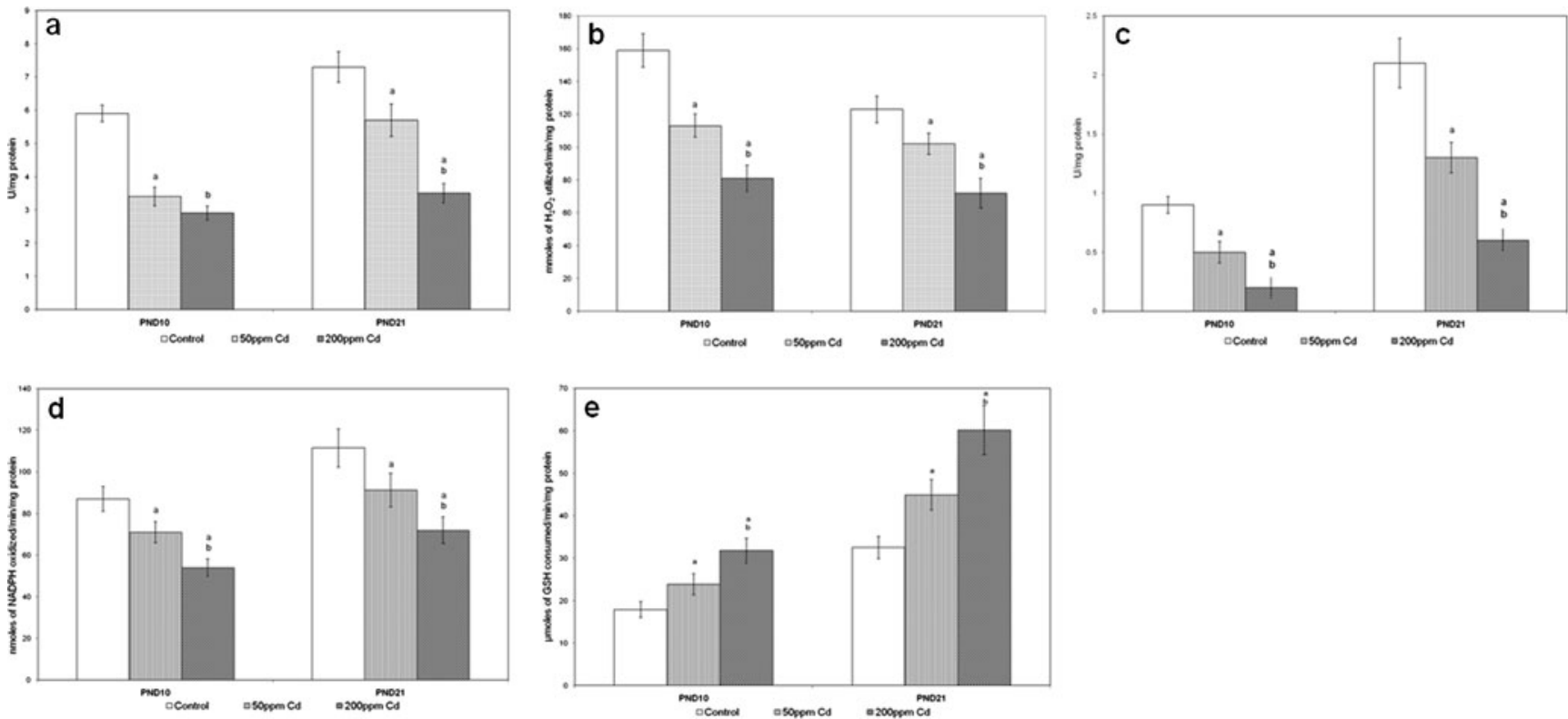

Fig. 5 Effect of gestational exposure to $\mathrm{Cd}$ on the specific activities of ovarian SOD (a), catalase (b), GPx (c), GR (d), and GST (e). Each bar represents the mean and the vertical line above denotes the SEM of 24 female rats (from six mothers). See "Materials and Methods" for

production of steroids. The decrease in body weight and ovary weight in animals exposed to $\mathrm{Cd}$ is consistent with previous observations [29, 31]. The observed decrease in food and water consumption in Cd-treated animals might be responsible for reduced body and ovary weight. It has been reported that the feto-placental unit is considered as a target for $\mathrm{Cd}$ toxicity mainly during third trimester of gestation in rodents [32]. Progesterone and estrogen are required to maintain pregnancy. Optimal levels of gonadotropins are required for steroid hormone production [33]. Hence, the observed decrease in the levels of testosterone, estradiol, and progesterone in Cd-treated rats may be due to impaired gonadotropin levels reported in an earlier study [34]. Further, enzymes required for the biosynthesis of ovarian steroid hormones have been shown to be affected [29]. experimental details. Statistical significance of difference among groups at $p<0.05$. Control versus experiment $(a)$; 50 versus $200 \mathrm{ppm}(b)$

Hence, the decline in the levels of ovarian hormones might be mediated through impaired gonadotropin levels and/or steroidogenic enzymes.

In the present study, $\mathrm{Cd}$ treatment exhibited a pubertal delay in a dose-dependent manner compared to control rats with an extended estrous cycle. Rat estrous cycle averages 4 to 5 days in length, occurs throughout the year without seasonal influence in laboratory colonies, and occurs from pubertal onset until senescence. The cycle consists of four stages; proestrous $(12 \mathrm{~h})$, estrous $(12 \mathrm{~h})$, metestrus $(21 \mathrm{~h})$, and diestrus $(57 \mathrm{~h})$. During metestrus and diestrus, the female will not accept males, and the vaginal cytology have lots of leukocytes. This stage had the signs of estrogen stimulation subside and the corpus luteum starts to form and the uterine lining begins to secrete progesterone [35].
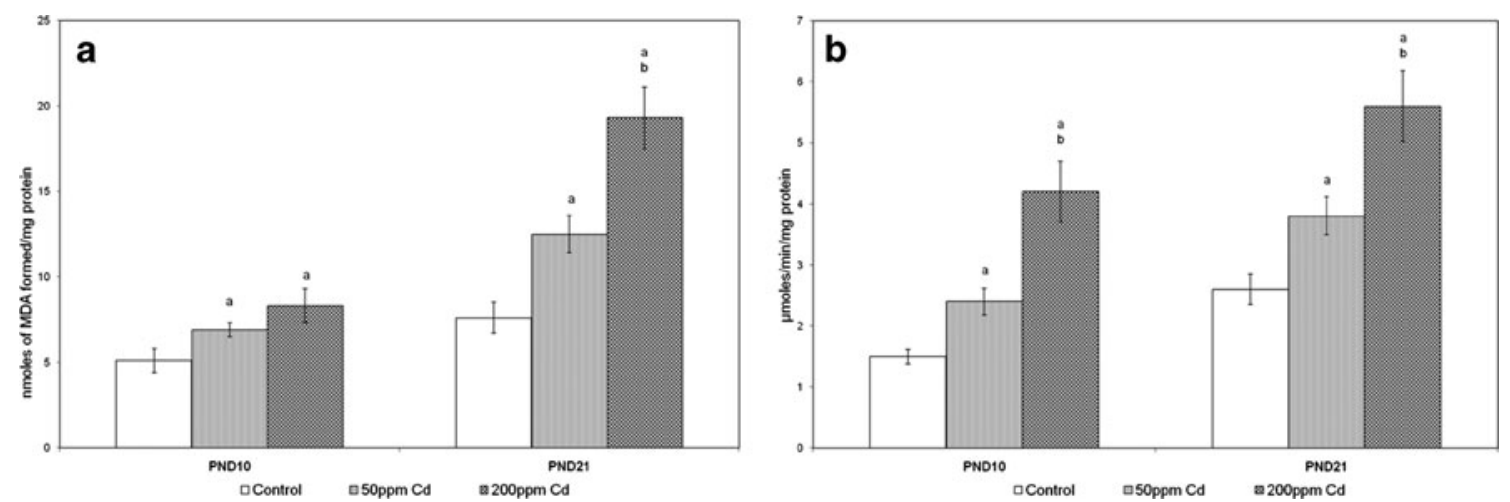

Fig. 6 Effect of gestational exposure to Cd on the specific activities of ovarian LPO (a), and $\mathrm{H}_{2} \mathrm{O}_{2}$ (b). Explanations and $n$ values are same as given under Fig. 5 
Table 4 Effect of gestational exposure to $\mathrm{Cd}$ on circulating levels of steroid hormones in developing rats (PND 10 and 21)

Explanations and $n$ values are same as given under Table 2

\begin{tabular}{|c|c|c|c|c|c|c|}
\hline & \multicolumn{2}{|c|}{ Testosterone $(\mathrm{ng} / \mathrm{mL})$} & \multicolumn{2}{|c|}{ Estradiol (pg/mL) } & \multicolumn{2}{|c|}{ Progesterone $(\mathrm{ng} / \mathrm{mL})$} \\
\hline & PND10 & PND21 & PND10 & PND21 & PND10 & PND21 \\
\hline Control & $0.81 \pm 0.05$ & $0.17 \pm 0.02$ & $23.8 \pm 1.5$ & $38.7 \pm 2.7$ & $2.8 \pm 0.8$ & $4.9 \pm 1.3$ \\
\hline $50 \mathrm{ppm} \mathrm{Cd}$ & $0.68 \pm 0.06^{\mathrm{a}}$ & $0.11 \pm 0.01^{\mathrm{a}}$ & $20.1 \pm 1.3^{\mathrm{a}}$ & $31.4 \pm 2.1^{\mathrm{a}}$ & $2.1 \pm 1.1$ & $3.1 \pm 1.1$ \\
\hline $200 \mathrm{ppm} \mathrm{Cd}$ & $0.52 \pm 0.03^{\mathrm{a}, \mathrm{b}}$ & $0.07 \pm 0.01^{\mathrm{a}, \mathrm{b}}$ & $17.9 \pm 1.6^{\mathrm{a}, \mathrm{b}}$ & $23.9 \pm 1.7^{\mathrm{a}, \mathrm{b}}$ & $1.2 \pm 0.6^{\mathrm{a}}$ & $2.7 \pm 0.5^{\mathrm{a}}$ \\
\hline
\end{tabular}

Earlier, we have reported permanent damage to ovarian primordial and primary follicles in Cr-exposed rats [28, 30] with extended estrous cycle [20]. In a similar way, $\mathrm{Cd}$ might have caused damage to ovary, which might contribute to the delayed pubertal onset and extended estrous cycle. These observations together highlight the deleterious effects of heavy metals on female reproductive system.

Hematological parameters indicate the sub-lethal effects of pollutants [36]. Anemia has been observed in rats, mice, rabbits, and monkeys exposed to $\mathrm{Cd}$. The data on hematological indices indicate that the animals exposed to $\mathrm{Cd}$ were in anemic condition. It is reported that oral $\mathrm{Cd}$ treatment reduces gastrointestinal uptake of iron, which can result in anemia [37]. It was well known that anemia reduces the supply of oxygen to tissues by lowering the oxygen-carrying capacity of the blood. This finding is consistent with previous studies of anemia in rodents exposed to $\mathrm{Cd}$ [38]. The present study showed that toxic effects of $\mathrm{Cd}$ leads to decreased hemoglobin, hematocrit, and M.C.V. levels in both age groups of Cd-treated rats. Reduction in food intake in these rats might have also contributed to reduced $\mathrm{Hb}$ levels.

Antioxidant enzymes play essential part in the cellular defense against free radical-mediated tissue or cellular damage. The involvement of oxidative stress in $\mathrm{Cd}$ induced cellular toxicity was known [29]. Data from the present study on antioxidant and free radicals clearly suggest the onset of oxidative stress in the ovary of Cdtreated rats, as there was a significant increase in the concentration of $\mathrm{H}_{2} \mathrm{O}_{2}$ and LPO and subnormal activity of most of the antioxidant enzymes tested. Cd-induced production of ROS was reported [39], and ROS may propagate the initial attack on lipid membranes to cause lipid peroxidation [40]. Data on $\mathrm{H}_{2} \mathrm{O}_{2}$ and LPO point out the dose-dependent increase in $\mathrm{H}_{2} \mathrm{O}_{2}$ and LPO levels. The increase in $\mathrm{H}_{2} \mathrm{O}_{2}$ might have induced the peroxidation of polyunsaturated fatty acids and lead to the formation of MDA, one of the by-products of lipid peroxidation. In the present study, the observed increase in LPO level indicates the oxidative stress formed. Estradiol being a physiological antioxidant, its deficiency has been shown to be associated with oxidative stress [41]. Thus, in the present study, the impaired level of serum steroids might have lead to increased level of LPO.
SOD is considered as the first line of defense against harmful effects of oxyradicals in cells by catalyzing the removal of superoxide radical $\left(\mathrm{O}_{2}{ }^{-}\right)$, which damage the membrane and biological structures. The decrease in SOD activity may result in more accumulation of $\mathrm{O}_{2}{ }^{-}$, which in turn may inhibit other antioxidant enzymes. Stajn et al. [42] and Sarkar et al. [43] reported the Cd-induced decrease in SOD levels in erythrocytes and kidneys. Casalino et al. [44] demonstrated that SOD activity is strongly inhibited by $\mathrm{Cd}$, probably by interacting with metal moieties of SOD $(\mathrm{Cu}$, $\mathrm{Zn}$, or $\mathrm{Mn}$ ) and thus reducing its activity. Reduced activity of SOD in ovary documented in the present study was in corroboration with previous reports [44]. The decrease in SOD activity in animals exposed to high dose of metals is associated with increased $\mathrm{O}_{2}{ }^{-}$, which has been shown to inhibit CAT. In this study, CAT level was decreased in ovary of the Cd-treated animals. Along with CAT, GPx is also involved in the scavenging of $\mathrm{H}_{2} \mathrm{O}_{2}$. GPx in particular play a significant role in scavenging peroxides such as $\mathrm{H}_{2} \mathrm{O}_{2}$ and protects cell membranes from lipid peroxidation [45]. GR is an important enzyme responsible for maintaining the intracellular concentration of reduced glutathione (GSH). In the present study, the levels of antioxidant enzymes viz. SOD, CAT, GST, GR, GPx were decreased in ovary of Cdtreated rats.

$\mathrm{Cd}$ treatment-induced disruption of ovarian histoarchitecture was reported [46]. Recently, Gurel et al. [47] reported the ovarian follicular cell damage in $\mathrm{Cd}$-treated female rats. The present study showed that gestational $\mathrm{Cd}$ treatment caused histoarchitectural changes in follicular cells and oocytes, with disruption of the follicles, deorganized cells, and shrunken oocytes. Thus, the present study revealed the ovo-toxic nature of $\mathrm{Cd}$.

\section{Conclusion}

Based on the results from the present study, it may be concluded that gestational exposure to $\mathrm{Cd}$ affects the female reproductive health. Our results revealed that $\mathrm{Cd}$-induced changes in the ovarian function are associated with altered ovarian histoarchitecture, oxidative stress, anemia, and delayed puberty with impaired steroid hormone levels. 
The present study taken together with earlier studies suggests the toxic effects of $\mathrm{Cd}$ on reproduction in laboratory animals and warrants investigations in human.

Conflict of interest The authors declare that there is no conflict of interest that would prejudice the impartiality of this scientific work.

\section{References}

1. WHO (1992) Cadmium, environmental health criteria no. 134. WHO, Geneva

2. Gaweda E (2003) Chemical hazards induced by heavy metals refining processes. Med Pr 54:543-548

3. Henson MC, Anderson MB (2000) The effects of cadmium on placental endocrine function. Recent Res Dev Endocrinol 1:37-47

4. Massanyi P, Lukac N, Uhrin V et al (2007) Female reproductive toxicology of cadmium. Acta Biol Hung 58:287-299

5. Varga B, Zsolnai B, Paksy K, Naray M, Ungvary G (1993) Age dependent accumulation of cadmium in the human ovary. Reprod Toxicol 7:225-228

6. Jancova A, Massanyi P, Nad P et al (2006) Accumulation of heavy metals in selected organs of yellow-necked mouse. Ekologia 25:19-26

7. Korenekova B, Skalicka M, Nad P (2002) Cadmium exposure of cattle after long-term emission from polluted area. Trace Elem Electrolytes 19:97-99

8. Bhattacharyya MH, Wilson AK, Rajan SS, Jonah M (2000) Biochemical pathways in cadmium toxicity. In: Zalup RK, Koropatnick J (eds) Molecular biology and toxicology of metals. Taylor and Francis, London, pp 1-74

9. U.S. Geological Survey 2010, Mineral Commodity Summaries; 36-37

10. Sethi PK, Khandelwal D (2006) Cadmium exposure: health hazards of silver cottage industry in developing countries. J Med Toxicol 2:14-15

11. Panchal L, Vaideeswar P (2006) Acute lung injury due to cadmium inhalation - a case report. Indian J Pathol Microbiol 49:265-266

12. Henson MC, Chendrese PJ (2004) Endocrine disruption by cadmium, a common environmental toxicant with paradoxical effects on reproduction. Exp Biol Med 229:383-392

13. Bhattacharyya MH, Whelton BD, Peterson DP (1982) Gastrointestinal absorption of cadmium in mice during gestation and lactation. II. Continuous exposure studies. Toxicol Appl Pharmacol 66:368-375

14. Whelton BD, Toomey JM, Bhattacharyya MH (1993) Cadmium109 metabolism in mice. IV. Diet versus maternal stores as a source of cadmium transfer to mouse fetuses and pups during gestation and lactation. J Toxicol Environ Health 40:531-546

15. Ekine RS, Agu GO (2005) Fetal contamination with cadmium following chronic exposure of rat dams during gestation. Afr J Appl Zool Environ Biol 7:120-124

16. Samawarickrama GP, Webb M (1981) The acute toxicity and teratogenecity of cadmium in pregnant rat. J Appl Toxicol 1:264269

17. Levin A, Miller RK (1981) Fetal toxicity of cadmium in the rat: decreased utero-placental blood flow. Toxicol Appl Pharmacol 58:297-306

18. Salpietro CD, Gangemi S, Minciullo PL, Briuglia S, Merlino MV, Stelitano A, Cristani M, Trombetta D, Saija A (2002) Cadmium concentration in maternal and cord blood and infant birth weight: a study on healthy non-smoking women. J Perinat Med 30:395399

19. Laudanski T, Sipowicz M, Modzelewski P, Bolinski J, Szamatowicz J, Razniewska G, Akerlund M (1991) Influence of high lead and cadmium soil content on human reproductive outcome. Int $\mathrm{J}$ Gynecol Obstet 366:309-315

20. Samuel JB, Stanley JA, Roopha DP, Vengatesh G, Anbalagan J, Banu SK, Aruldhas MM (2011) Lactational hexavalent chromium exposure-induced oxidative stress in rat uterus is associated with delayed puberty and impaired gonadotropin levels. Hum Exp Toxicol 30:91-101

21. Lowry OH, Rosebrough NJ, Farr AL, Randall RJ (1951) Protein measurement with the Folin phenol reagent. J Biol Chem 193:265-275

22. Marklund S, Marklund G (1974) Involvement of super oxide anion radical in the auto oxidation of pyrogallol and a convenient assay for super oxide dismutase. Eu J Biochem 47:469-474

23. Sinha AK (1972) Colorimetric assay of catalase. Anal Biochem 47:389-394

24. Rotruck JT, Pope AL, Ganther HE, Swanson AB, Hafeman DG, Hoekstra WG (1973) Selenium: biochemical role as a component of glutathione peroxidase. Science 179:588-590

25. Habig WH, Pabst MJ, Jakoby WB (1973) Glutathione-S-tranferase. The first enzymatic step in mercapturic formation. J Biol Chem 249:7130-7139

26. Stall GEJ, Vegel C (1969) Purification and properties of glutathione reductase of human erythrocytes. Biochim Biophys Acta 185:39-48

27. Devasagayam TPA, Tarachand V (1987) Decreased lipid peroxidation in the rat kidney during gestation. Biochem Biophys Res Comm 145:134-138

28. Banu SK, Samuel JB, Arosh AJ, Burghard CR, Aruldhas MM (2008) Lactational exposure to hexavalent chromium delays puberty by impairing ovarian development, steroidogenesis and pituitary hormone synthesis in developing Wistar rats. Toxicol Appl Pharmacol 232:180-189

29. Nampoothiri LP, Agarwal A, Gupta S (2007) Effect of coexposure to lead and cadmium on antioxidant status in rat ovarian granulose cells. Arch Toxicol 81:145-150

30. Royce R, Samuel JB, Arosh JA, Lee J, Aruldhas MM, Banu SK (2007) Chromium toxicity induces ovarian follicular developmental arrest, apoptosis, and deregulated steroidogenesis: vitamin $\mathrm{C}$ restores follicular survival and function. Biol Reprod 77:215

31. Ronco AM, Urrutia M, Montenegro M, Llanos MN (2009) Cadmium exposure during pregnancy reduces birth weight and increases maternal and foetal glucocorticoids. Toxicol Lett 188:186-191

32. Parizek J (1983) Cadmium and reproduction: a perspective after 25 years. In: Clarkson TW, Nordberg GF, Sager PR (eds) Reproductive and developmental toxicity of metals. Plenum, New York, pp 310-313

33. Paksy K, Rajczy K, Forgacs Z, Lazar P, Bernard A, Gati I, Kaali GS (1997) Effect of cadmium on morphology and steroidogenesis of cultured human ovarian granulosa cells. J Appl Toxicol 17:321-327

34. Priya PN, Pillai A, Gupta S (2004) Effect of simultaneous exposure to lead and cadmium on gonadotropin binding and steroidogenesis on granulosa cells: an in vitro study. Indian J Exp Biol 42:143-148

35. Lohmiller JL, Swing SP (2006) Reproduction and breeding. In: Suckow MA, Weisbroth SH, Franklin CL (eds) The laboratory rat, 2nd edn. Elsevier Academic, California, pp 147-164

36. Larsson A, Haux C, Sjobeck ML (1985) Fish physiology and metal pollution: results and experiences from laboratory and field studies. Ecotoxicol Environ Saf 9:250-281

37. ATSDR (1999) Toxicological profile for cadmium. Agency for Toxic Substances and Disease Registry, Atlanta 
38. Dallak M (2009) Camel's milk protects against cadmium chlorideinduced hypocromic microcytic anemia and oxidative stress in red blood cells of white albino rats. Am J Pharmacol Toxicol 4:134141

39. Stohs SJ, Bagchi D, Hassoun E, Bagchi M (2001) Oxidative mechanisms in the toxicity of chromium and cadmium ions. $\mathrm{J}$ Environ Pathol Toxicol Oncol 20:77-88

40. Sugino N, Shimamura K, Takiguchi S (1996) Changes in activity of superoxide dismutase in the human endometrium throughout the menstrual cycle and in early pregnancy. Hum Reprod 1:10731078

41. Sugiyama M (1994) Role of cellular antioxidants in metal-induced damage. Cell Biol Toxicol 10:1-22

42. Stajn A, Zikic RV, Ognjanovic B, Saicic ZS, Pavlovic SZ, Kostic MM, Petrovic VM (1997) Effect of cadmium and selenium on the antioxidant defense system in rat kidneys. Comp Biochem Physiol 117:167-172
43. Sarkar S, Yadav P, Bhatnagar D (1998) Lipid peroxidative damage on cadmium exposure and alterations in antioxidant system in rat erythrocytes: a study with relation to time. Biometals 11:153-157

44. Casalino E, Sblano C, Landriscina C (1996) A possible mechanism for initiation of lipid peroxidation by ascorbate in rat liver microsomes. Int J Biochem Cell Biol 28:137-149

45. Samanta L, Roy A, Chainy GBN (1999) Changes in rat testicular antioxidant defense profile as a function of age and its impairment by hexachlorocyclohexane during critical stages of maturation. Andrologia 31:84-90

46. Massanyi P, Uhrin V, Sirotkin AV, Toman R, Pivko J, Rafay J, Forgacs Z, Somosy Z (2000) Effects of cadmium on ultrastructure and steroidogenesis in cultured porcine ovarian granulosa cells. Acta Vet Brno 69:101-106

47. Gurel E, Caner M, Bayraktar L, Yilmazer N, Dogruman H, Demirci C (2007) Effects of artichoke extract supplementation on gonads of cadmium-treated rats. Biol Trace Elem Res 119:51-59 